\title{
The potential of palaeoecological studies in archaeological wetland sites of the southern Baltic regions
}

\author{
Stefanie Jacomet $\cdot$ Małgorzata Latałowa $\cdot$ \\ Felix Bittmann
}

Received: 26 March 2014/ Accepted: 22 April 2014/Published online: 7 May 2014

(C) Springer-Verlag Berlin Heidelberg 2014

The ancient lake settlement tradition is not characteristic of one particular geographical area or time period, but it is spread over various European regions and dates from the Neolithic to the Middle Ages (Menotti and O'Sullivan 2013). Already in the 19th century, lake settlements were discovered in the Baltic region as well as elsewhere. Although research concentrated on sites in Poland up to the end of the 20th century (Pydyn and Gackowski 2011; Pranckènaite 2014, this volume), recent discoveries have directed attention to Lake Luokesa (Luokesai ežeras), Lithuania, as the five articles in the present issue show. The Luokesa lake settlements L1 and L2, dated to the transition from the Late Bronze Age to the Early Iron Age, were discovered at the very beginning of the 21 st century and excavated between 2000 and 2011.

The excavation (mainly of L1) was carried out underwater and revealed a thick cultural layer, containing extraordinarily well preserved organic material, which allowed an unprecedented interdisciplinary palaeoecological investigation. In contrast, site L2 which was located on

\footnotetext{
S. Jacomet $(\square)$

Department of Environmental Sciences, Basel University, Institute for Prehistory and Archaeological Science, Spalenring 145, 4055 Basel, Switzerland

e-mail: stefanie.jacomet@unibas.ch

\section{Latałowa}

Laboratory of Palaeoecology and Archaeobotany, Department of Plant Ecology, University of Gdańsk Ul, Wita Stwosza 59, 80803 Gdańsk, Poland

e-mail: m.latalowa@ug.edu.pl

F. Bittmann

Lower Saxony Institute for Historical Coastal Research,

Viktoriastr. 26/28, 26382 Wilhelmshaven, Germany

e-mail: bittmann@nihk.de
}

the opposite side of the lake consisted of a barren wooden platform without any cultural layers.

Excavations were carried out by a team from the Department of Archaeology at Vilnius University and the Lithuanian Cultural Heritage Centre which included Z. Baubonis, R. Kraniauskas, M. Kvedaravičius, G. Motuzaitè-Matuzevičiūtè, E. Pranckènaitė and numerous volunteers. Part of the excavations and, above all, the entire palaeoecological investigations, which comprised soil micromorphology, pollen and plant macroremain analyses and dendrochronological studies carried out between 2008 and 2011, were fully funded by the Swiss National Foundation for Scientific Research within the Project "Understanding human occupation in later prehistoric Europe" (No. NF K-13K1-117893), directed by Francesco Menotti (IPAS, Basel University).

The first article by E. Pranckenaite gives a comprehensive overview of the history of lake settlement research in north-eastern Europe. The excavated settlement structures and finds at L1 and L2 are presented and the importance and unusual nature of the settlements stressed. Formerly raised hypotheses and interpretations of the origins as well as the development and use of the region's lake settlements are discussed. This article forms an important review and starting point for the other papers dealing with the Luokesa sites, which present results of dendrochronology, geoarchaeology, palynology and archaeobotany.

The dendrochronological study by N. Bleicher allows the Luokesa lake settlements to be placed within a precise Late Bronze/Early Iron Age (LBA/EIA) chronology for the first time. A 90 year long floating chronology of the settlement could be established and fitted to the time axis by wiggle-matching radiocarbon dates to 625 and $535 \mathrm{BC}(2 \sigma$ range). The duration of the settlements however was much shorter, for example L1 was in use for only ca. 16 years. 
The aims of the micromorphological, pollen and archaeobotanical studies were to find out more about the taphonomy and genesis of the layers, possible seasonal activities, and the economy and environment of L1. This was based on a comprehensive sampling programme using profile columns. Several such columns were investigated from a lake to land transect, including ones from the centre of the settlement. The sampling of the columns was performed in close collaboration with the micromorphologists, palynologists and archaeobotanists. Concerning sampling, but also recovery of the macroremains, the methods developed in the circum-alpine lake settlement region by working groups at Lake Constance and Oberschwaben, Germany (mainly U. Maier) and at IPAS (Basel University) were applied, transferring this know-how to northeastern Europe (see for example Hosch and Zibulski 2003; Jacomet and Brombacher 2005; Vandorpe and Jacomet 2007; Tolar et al. 2010; Maier and Harwath 2011; IsmailMeyer et al. 2013).

The micromorphological study by K. Ismail-Meyer shows the potential of micromorphology for interpreting sedimentation processes in wetland sites. Natural processes and ones caused by humans that led to the formation of the individual layers are presented; their possible origins are discussed and compared to lakeside settlements of the circum-alpine region. Within the culture layer that formed in a waterlogged environment, indications of seasonal deposition cycles have been identified.

The pollen analytical study by A. Heitz-Weniger is based on five pollen diagrams, comprising the underlying lake marl and the cultural layer of L1. Woodland history, starting from the late Atlantic period, is recorded. The paper also discusses layer formation processes such as water level fluctuations and sediment gaps. As the settlement was located on damp ground at the time of occupation, water influences alternating with dry episodes have been observed. Pollen analyses of sheep/goat coprolites also provide information on the grazing season and location of pastures.

The plant macroremains study by B. Pollmann elucidates the history and crop diversity of settlement. The plant spectrum shows that the settlement was built on an exposed morainic shoal and it was surrounded by woodland, meadows, fields/gardens, ruderal habitats and riverine vegetation. Accumulated cultural deposits consisted mainly of manure (litter, fodder and dung of sheep/goat), with rubbish, sweepings from the houses or remains of the onsite vegetation. There was a large diversity of crops including Camelina sativa (gold-of-pleasure), which is the first evidence of this crop in prehistoric Lithuania. The results are discussed within a broader context of the LBA/ EIA cultural groups in central and north-eastern Europe.

Two papers present the most recent development of vegetation history under human impact in the Masurian
Lake District in north-eastern Poland, a region not too far away from the region of Luokesa. The paper by Szal et al. investigates pollen, non-pollen palynomorphs, charcoal and geochemistry of sediments at Lake Salęt. Human-induced vegetation changes related to the activities of the West Balt tribes during the Iron Age, between the second half of the 7 th century $\mathrm{BC}$ and the beginning of the 10th century $\mathrm{AD}$ have been reconstructed. There, woodland clearance around the lake started at the end of the 7 th century BC, which coincides with L1. Finally, the paper of Wacnik et al. deals with the Late Iron Age and medieval periods in the Masurian Lake District and provides new data for the reconstruction of vegetation changes related to human activity between the 1st and 13th centuries AD. The archaeobotanical data from samples taken in a cemetery and a large settlement of the Roman Iron Age supplements the off-site pollen study in various ways-of special interest are grass tubers probably belonging to Phleum pratense that have been found in the cemetery.

\section{References}

Hosch S, Zibulski P (2003) The influence of inconsistent wet-sieving procedures on the macroremains concentration in waterlogged sediments. J Archaeol Sci 30:849-857

Ismail-Meyer K, Rentzel Ph, Wiemann Ph (2013) Neolithic lakeshore settlements in Switzerland: new insights on site formation processes from micromorphology. Geoarchaeology 28:317-333

Jacomet S, Brombacher C (2005) Reconstructing intra-site patterns in Neolithic lakeshore settlements: The state of archaeobotanical research and future prospects. In: Della-Casa P, Trachsel M (eds) WES'04 - Wetland economies and societies (Collectio Archaeologica 3). Chronos, Zürich, pp 69-94

Maier U, Harwath A (2011) Detecting intra-site patterns with systematic sampling strategies. Archaeobotanical grid sampling of the lakeshore settlement Bad Buchau-Torwiesen II, southwest Germany. Veget Hist Archaeobot 20:349-365

Menotti F, O'Sullivan A (2013) The Oxford handbook of wetland archaeology. Oxford University Press, Oxford

Pranckenaite E (2014) Living in wetlands in the south-eastern Baltic Sea region during the Late Bronze-Early Iron Age: the archaeological context of the Luokesa lake-dwellings. Veget Hist Archaeobot 23 (this volume)

Pydyn A, Gackowski J (2011) Wetland archaeology of the Late Bronze Age and the Early Iron Age settlements from Poland. In: Pranckenaite E (ed) Wetland settlements of the Baltic. A prehistoric perspective. Center of underwater archaeology, Vilnius, pp 133-150

Tolar T, Jacomet S, Velušček A, Čufar K (2010) Recovery techniques of waterlogged archaeological sediments: a comparison of different treatment methods of samples from Neolithic lake shore settlements. Veget Hist Archaeobot 19:53-68

Vandorpe P, Jacomet S (2007) Comparing different pre-treatment methods for strongly compacted organic sediments prior to wetsieving: a case study on Roman waterlogged deposits. Environ Archaeol 12:207-214 